\title{
Hepatic Complication
}

National Cancer Institute

\section{Source}

National Cancer Institute. Hepatic Complication. NCI Thesaurus. Code C115224.

Any disorder of the liver occurring as a consequence of injury to the liver parenchyma. 